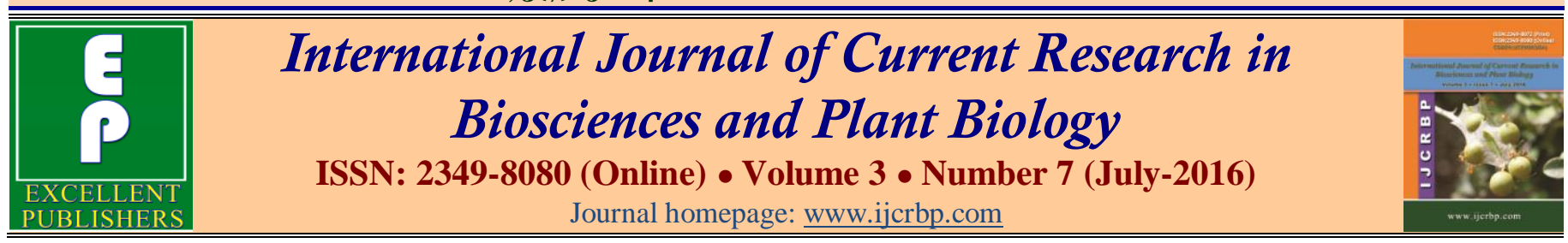

\title{
Cyanogenic Acid (HCN) Concentration in Leaves of Four Cassava Varieties and Resistance to Anthracnose Disease in Cameroon
}

\section{Ambang Zachee ${ }^{*}$, Maho Yalen Josian Edson',2, Essono Germain Gabriel3, Ndongo Bekolo and Heu Alain ${ }^{1}$}

${ }^{1}$ Department of Plant Biology, University of Yaoundé 1, Laboratory of Phytopathology and Microbiology, P.O. BOX 812

Yaounde, Cameroon

${ }^{2}$ Department of Biology, Higher Training College, University of Yaoundé 1, Cameroon

3Department of Microbiology, University of Yaoundé 1, Cameroon

*Corresponding author.

\begin{abstract}
Cassava anthracnose disease (CAD) is one of important fungal disease of cassava which attacks stem and leaves, consequently leading to low yield and even plant death. This study was carried out to determine the relation between cyanogenic (HCN) concentration in leaves from four cassava cultivars and their tolerance to CAD. One local cultivar (CV1) and three improved (CV2, CV3, CV4) were used in a randomized block design. Disease severity, incidence, concentration of HCN in leaves, inhibitory effects of HCN extract (in vitro) were evaluated. The cyanide concentration was determined by titration using a solution of $0.02 \mathrm{~N} \mathrm{AgNO}_{3}$. Low cyanide cultivars CV1 and $\mathrm{CV} 3$ with mean values of $\mathrm{HCN}, 0.5$ and $0.6 \mathrm{mg} / \mathrm{g}$ respectively were more susceptible to CAD (average severity 12.9 and 10.2\%). While, high acid cultivars CV2 $(1.1 \mathrm{mg} / \mathrm{g}), \mathrm{CV} 4(1.2 \mathrm{mg} / \mathrm{g})$ showed the highest tolerance to CAD $(4.0 \%$ severity on both cultivars). HCN extracts had inhibited 87.5 and $51.2 \%$ of Colletotrichum gloeosporioides growth at day 1 and day 7 respectively after incubation. A direct relationship existed between $\mathrm{HCN}$ in cassava leaves and tolerance to CAD. The capacity of cassava to synthesize $\mathrm{HCN}$ can be used in selection programs to obtain cassava cultivars resistant to CAD.
\end{abstract}

\section{Introduction}

Cassava (Manihot esculenta Crantz) is produced in most African countries (Nigeria, Cameroon, Uganda, Ghana, Kenya, Ivory Coast, Benin, etc.) and it is an important food for human and animal feed (Louembé et al., 2002; Olubamila et al., 2001). It ranks among the top ten most significant food crops produced in developing countries (Lozano et al., 1981; Scott et al., 2000). The crop is a main and cheapest source of carbohydrates for millions of people in most African towns where population increase is very rapid (Sanni et al., 2005). Cassava can

\section{Article Info}

Accepted: 19 June 2016

Available Online: 06 July 2016

Keywords

Anthranose disease

Biocontrol

Cassava

Cyanogenic acid

Host resistance grow in very poor soils compared to cereals. It can be considered as the most important crop to alleviate poverty and hunger in Africa. In industries, it is used as a raw material for starch and alcohol production (Wrigth, 1996).

Pests and diseases constitute a major constraint to the production of root and tuber crops in Africa (Coursey and Brooth, 1977; Obame Minko and Békon, 2005; Obilo et al., 2010). Cassava is particularly attack by viruses, bacteria, nematodes and fungi (Fauquet and Fargette, 1990; Babu et al., 2008). These pathogens may 
infect the foliage, roots or tubers causing plant weakness, premature death and rotten or poor quality tubers, leading to great losses in yield (Fews, 1998; Wood and Jellis, 1984; Were et al., 2007). The most damaging plant diseases are caused by fungi and serious losses (20$100 \%$ ) sometimes occur in the year of primary infection (Bilgrami and Dube, 1984).

Cassava anthracnose disease (CAD) is an important disease of both stems and leaves of cassava. CAD is caused by Colletotrichum gloeosporioides Penz f.sp. manihotis, which belongs to class Deuteromycetes and family Melanconiaceae (Makambila, 1987; Marley and Ajayi, 2003).The disease causes cankers of the stems, twigs and fruit. On the young stem a patch of greenish tissue develop into lesions which turns brown and disrupt translocation of water, minerals and photosynthetic matters within the plant. In older stems the lesions develop into deep cankers which cause stems to be brittle and easily break under strong winds (Obilo et al., 2010).

The physical damage caused on the stems does not only permit entry of secondary pathogens but result in stems of inferior quality which may as a consequence, yields reducing (Muyolo, 1984; Fokunang et al., 2000). Leaf spotting and tip die back seriously affects photosynthetic efficiency of the leaves and this can bring out a correlation between disease incidence and severity with yield loss and even plant death. Preliminary screening results indicate that use of less tolerant varieties can increase crop losses due to CAD (Ikotun and Osiru, 1990; Nkalubo et al., 2007; Obilo et al., 2010). Studies realized by Muyolo (1984) and Makambila (1987) reported that $80-90 \%$ of local cultivars were rated as severely infected in Zaire and Congo (Owolade et al., 2006).

Several methods (chemical, cultural, genetic and biological) are used to control cassava diseases (Ambang et al., 2007; Ouzounov, 1988). The chemical method which is the most widely used has a number of advantages and presents harmful consequences on the environment.

Recourse to resistant or tolerant cultivars is gaining interest in most research programs in plant protection and sustainable agriculture (Fokunang et al., 2002; Owolade et al., 2005). Cyanogenic substances (linamarin and lotaustralin) are a group of phytocide compounds synthesized by cassava (Bruitn, 1973). These glycosides after hydrolysis produce $\mathrm{HCN}$ which has a high inhibitory effect on aerobic respiration (Conn, 1973; Harborne, 1998). In recent years, a number of works have been interested in understanding the role of cyanogenic substances on cassava's natural defence (Belloti and Riis, 1994; Githunguri et al., 2007; Akinbo et al., 2007; De Silva et al., 2009; Ambang et al., 2009; Kunkeaw et al., 2010). From studies of rubber, barley and other plants, it was demonstrated that cyanogenic glycosides are involved in natural plant defence (Lieberei, 1988a; Osbourn, 1996; Nielsen et al., 2002). This study reports on the relationship between cyanogenic acid concentration of cassava ( $M$. esculenta) leaves and tolerance to anthracnose disease caused by $C$. gloeosporioides.

\section{Materials and methods}

\section{Site description, land preparation and experiment layout}

The field study was carried out in Cameroon from August 2005 to April 2006 in the experimental station of the Department of Plant Biology, University of Yaounde I. The laboratory experiments were realized in the laboratory of "Phytopathology and Microbiology" of the same department, and in the laboratory of plant and food control of the IMPM at the Ministry of Scientific Research and Innovation in Yaounde. The soil of experimental site is classified as ferruginous. It is a well drained sandy loam soil, $\mathrm{pH}=5.52-6.0$, total $\mathrm{N}=0.038$ $\%$, total $\mathrm{P}=60.5 \mu \mathrm{g} / \mathrm{g}$.

The Yaounde zone (Latitude $03^{\circ} 53^{\prime} \mathrm{N}$, Longitude $11^{\circ} 27^{\prime} \mathrm{E}$ with altitude of $700 \mathrm{~m}$ a.s.l.) has a bi-modal rainfall pattern (first rainy season from March to June, a dry spell in July and August followed by the second rainy season in September to November) with an average annual rainfall of $1600-2000 \mathrm{~mm}$ and temperature ranging between 21 and $29^{\circ} \mathrm{C}$ with relative humidity up to $85 \%$. Monthly average climate data during the experimental period were favorable to development of cassava cultivars (Table 1).

The land was cleared manually with a cutlass and the ridges were prepared using a hoe (Aiyelari et al., 2002). The experimental setup consisted of four blocks (replicates) with four treatments. The treatments were randomized in each of the four blocks. Block size was $26.5 \times 3 \mathrm{~m}$ with inter block spacing of $2.5 \mathrm{~m}$., while plot size was $5.5 \times 2.5 \mathrm{~m}$ with inter plot spacing of $1.5 \mathrm{~m}$. Treatments consisted of four cassava cultivars. 
Table 1. Monthly average climate data during the experimental period (August 2005 - April 2006) (source: meteorological station of Yaounde town).

\begin{tabular}{llllllllll}
\hline Climate parameters & Aug & Sep & Oct 2005 & Nov & Dec & Jan & Feb & $\begin{array}{l}\text { Mar } \\
\text { Apr }\end{array}$ \\
& $\mathbf{2 0 0 5}$ & $\mathbf{2 0 0 5}$ & & $\mathbf{2 0 0 5}$ & $\mathbf{2 0 0 5}$ & $\mathbf{2 0 0 6}$ & $\mathbf{2 0 0 6}$ & $\mathbf{2 0 0 6}$ & $\mathbf{2 0 0 6}$ \\
\hline Rainfall $(\mathrm{mm})$ & 27.0 & 184.7 & 251.6 & 73.7 & 13.8 & 11.4 & 66.6 & 104.6 & 205.3 \\
Humidity $(\%)$ & 84.0 & 82.0 & 85.0 & 81.0 & 83.0 & 84.0 & 81.0 & 85.0 & 85.0 \\
Temperature $\left({ }^{\circ} \mathrm{C}\right)$ & 23.2 & 24.3 & 24.0 & 25.7 & 27.6 & 27.5 & 26.5 & 26.0 & 25.5 \\
\hline
\end{tabular}

\section{Plant material and cultural details}

Four cassava cultivars with different sensitivity to CAD (one local cultivar (CV): CV1=LMR; three improved: CV2 $=92 / 0326$, CV3 = 81/00110, CV4 = W94/009) were used. The four cultivars (healthy stems of ten months old) were obtained from the International Institute of Tropical Agriculture (IITA) Mbalmayo reserve plantation. Each cultivar (stem cutting about $20 \mathrm{~cm}$ length) was planted manually in each plot at an inclination of $45^{\circ}$ with almost $3 / 4$ of its length buried in the soil. Cuttings were planted on the $10^{\text {th }}$ of August 2005 at a spacing of $1 \times 0.8 \mathrm{~m}$ thereby giving 12500 stands per hectare and 78 cuttings per replicate (block). To maintain the plantation in good condition, weeding was done manually using a hoe from the fourth week after planting.

\section{Fungal material}

The strain of Colletotrichum gloeosporioides used was isolated from infected leaves and some parts of stem of one diseased cassava plant (chosen between infected plants in a farmer plantation near the experimental site) with typical CAD symptoms for in vitro testing. In laboratory, diseased organs were soaked in sterile distilled water for $10 \mathrm{~min}$ before sterilisation for $3 \mathrm{~min}$ by dipping into a solution of $10 \%$ sodium hypochlorite (Ritchie, 1991). They were rinsed with sterile water and dried using a filter paper. The sterilised leaves with anthracnose lesions were cut into pieces approximately $5 \times 10 \mathrm{~mm}$ at the edges of defined lesions. These pieces were placed on moist filter paper in Petri dishes of $90 \mathrm{~cm}$ in diameter (three or four pieces of leaves per dish) and were incubated for 7 days at $28^{\circ} \mathrm{C}$ in the dark to induce sporulation. After observation under the light microscope, the colonies hereby obtained were subcultured by transferring conidial masses onto Potato Dextrose Agar (PDA, Merck, Germany; 39 g/L) medium for purification and incubated again in the dark at $28^{\circ} \mathrm{C}$. After three or four successive subculturing on PDA medium, a pure culture of the isolate of Colletotrichum gloeosporioides was selected. After microscopic observation the colony was characterised by the salmon pink masses of conidia (Bakak, 1992). The concentration of the culture was determined $\left(3 \times 10^{6}\right.$ spores $\left./ \mathrm{ml}\right)$ by using the Malassez cell.

\section{Determination of disease tolerance and $\mathrm{HCN}$ concentration}

CAD symptoms appeared under natural conditions. HCN concentrations in leaves, severity and incidence of disease during the growing cycle were assessed twice (120 and 210 days after planting).

\section{Disease evaluation}

The incidence and severity of anthracnose was determined by using conventional phytopathological methods (Tchoumakov and Zaharova, 1990; Lepoivre, 2003). The incidence was determined by the formula:

$$
\mathrm{P}(\%)=(\mathrm{n} / \mathrm{N}) \times 100
$$

Where: $\mathrm{P}(\%)=$ Incidence of disease; $\mathrm{N}=$ Total number of plants on the plot (healthy and infected plants); $\mathrm{n}=$ Number of infected plants on the plot.

Disease Severity was determined according to the Tchumakov and Zaharova (1990) formula:

$$
I v=\frac{\sum(a b)}{N}
$$

Where: Iv $(\%)=$ Severity (Intensity) of infection on the plot; $\Sigma(\mathrm{ab})=$ Sum of the multiplications of number of diseased plants (a) with the corresponding degree of infection (b) expressed in \%; $\mathrm{N}=$ Total number of infected plants on the plot.

To determine the CAD severity, the proportions of infected leaves and stems showing disease symptoms on the surface of each organ were estimated in $\%$ by visual observation. CAD infection was confirmed in the laboratory after isolation of lesions on leaves and stems, their incubation on PDA medium followed by microscopic observation of mycelia and spores of $C$. gloeosporioides. 


\section{HCN assessment}

HCN concentration and dry matter in cassava leaves were evaluated twice at 120 days after planting (DAP), the beginning of the flowering phase and 210 DAP (tuber forming phase). To determine dry matter, six metallic Petri dishes were use for each variety. After weighing the dishes, $20 \mathrm{~g}$ of fresh leaves was put in each dish. The dishes were then introduced for $24 \mathrm{hrs}$ into an oven for drying. The dishes with dried leaves were weighed again after passing through the desiccator. The dry matter was determined according to the following formula:

$$
\mathrm{DM}(\%)=100-(\mathrm{Wf}-\mathrm{Wd} / \mathrm{Wf}-\mathrm{W} 0) \times 100
$$

Where: $\mathrm{DM}(\%)=$ percentage of dry matter; W0 = weight of an empty dish; Wf = weight of fresh leaves; $\mathrm{Wd}=$ weight of dry leaves.

HCN concentration was determined according to the alkaline method (Grace, 1978; Harborne, 1998). The extraction of cyanide glycosides was realized in a closed vessel through distillation method. Twenty grams of the fresh leaves were crushed and put into a distillation flask containing $200 \mathrm{~mL}$ of water. This was allowed to stand for two to four hours, in order to liberate all the bound hydrocyanic acid at different temperatures. The flask was kept connected to distillation apparatus. The hydrolysis of cyanogenic substances (e.g. Linamarin) follows the reaction (Fig. 1) (Mc Mahon and Sayre, 1994; Harborne, 1998). The distillate was collected in a closed flat bottom flask $(250 \mathrm{~mL}$ ) containing $20 \mathrm{~mL}$ of $2.5 \% \mathrm{NaOH}$ solution to trap HCN. Then, a $8 \mathrm{~mL}$ solution of potassium iodide (KI) was added to $100 \mathrm{~mL}$ of distillate before $\mathrm{HCN}$ concentration was determined by titration with $0.02 \mathrm{~N}$ $\mathrm{AgNO}_{3}\left(1 \mathrm{~mL}\right.$ of $\mathrm{AgNO}_{3}$ is equivalent to $1.08 \mathrm{mg}$ of $\mathrm{HCN}$ ) using a micro burette. The end point is indicated by a faint permanent turbidity which may be easily recognized, especially against a black background.
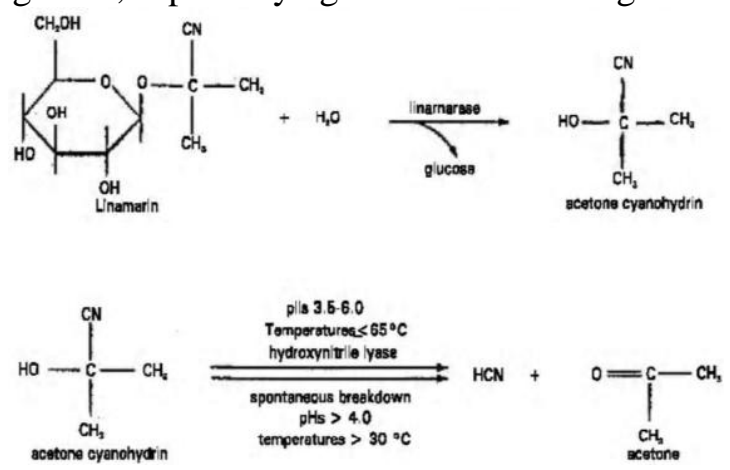

Fig. 1: Equation reaction of hydrolysis of linamarin (Mc Mahon and Sayre, 1994; Harborne, 1998).
Evaluation of fungal growth and inhibitory effect of HCN extract in vitro

Two doses of HCN extract ( 75 and $100 \mu \mathrm{L})$ were used to evaluate the inhibitory potential of $\mathrm{HCN}$ against $C$. gloeosporioides with 10 replicates. $\mathrm{HCN}$ extracts were added to the PDA medium before the solution had solidified. The control dishes had only culture medium. The explant (6 $\mathrm{mm}$ in diameter) of the fungal inoculum was placed in the centre of a Petri dish $(90 \mathrm{~cm}$ in diameter). All dishes with $\mathrm{HCN}$ extracts were hermetically closed with a transparent film. The radial diameter of the inoculum (mycelial growth) was measured daily for seven days in control and in plates treated with $\mathrm{HCN}$ extract. Inhibitory percentage (I\%) of the two doses of $\mathrm{HCN}$ extract was determined as compared to the control plate for seven days according to the formula (Singh et al., 1993):

$$
\mathrm{I}(\%)=\frac{\mathrm{Dt}-\mathrm{Dx}}{\mathrm{Dt}} \times 100
$$

Where: I $(\%)=$ inhibitory percentage; $\mathrm{Dt}=$ mean diameter of the culture with no extract; Dx = mean diameter of the culture with HCN extract.

\section{Statistical analysis}

The statistical analysis System (SAS) was used for the analysis of data. From ANOVA results Duncan Multiple Range Test at a probability level of $p<0.05$ were used to separate the means.

\section{Results}

\section{HCN concentrations in cassava leaves}

Data collected 120 DAP showed that dry matter (DM) varied from 30.3 to $32.8 \%$ in leaves of the four cassava cultivars, although there was no significant difference $(p>0.05)$ (Table 2). HCN concentration was higher in cultivar CV2 $(0.90 \mathrm{mg} / \mathrm{g})$ compared to those in CV3, CV4 and CV1 with $0.5,0.5$ and $0.4 \mathrm{mg} / \mathrm{g}$ respectively. From data (Table 2) of HCN collected at 210 DAP $(0.5$, $1.2,0.8$, and $1.8 \mathrm{mg} / \mathrm{g}$ for CV1, CV2, CV3 and CV4 respectively) and average data (Table 3 ) obtained during the experimentation $(0.5,0.6,1.1,1.2 \mathrm{mg} / \mathrm{g}$ for $\mathrm{CV} 1$, $\mathrm{CV} 3, \mathrm{CV} 2$ and $\mathrm{CV} 4$ respectively), two groups of cultivars were effectively distinguished based on their $\mathrm{HCN}$ concentration. For cultivars CV2 and CV4, HCN concentrations were averagely two to three times greater than those of cultivars CV1and CV3 (Table 2). 
Observations made at 210 DAP revealed a decrease in $\mathrm{DM}$ of all the cultivars, with relatively high levels of DM in cultivars with high $\mathrm{HCN}$ concentration (CV2 and CV4) compared to those with less acid (CV1 and CV3).

Table 2. Variation of dry matter (DM) and HCN concentration in cassava leaves 120 and 210 days after planting (DAP).

\begin{tabular}{lllll}
\hline \multirow{2}{*}{ Cassava cultivars } & \multicolumn{1}{l}{ DM $(\%)$} & \multicolumn{3}{l}{ HCN concentration $(\mathbf{m g} / \mathbf{g}$ of DM) } \\
\cline { 2 - 5 } CV-1 & 120 DAP & 210 DAP & 120 DAP & 210 DAP \\
CV-2 & $30.7 \mathrm{a}$ & $26.0 \mathrm{ab}$ & $0.4 \mathrm{~b}$ & $0.5 \mathrm{c}$ \\
CV-3 & $31.3 \mathrm{a}$ & $27.1 \mathrm{ab}$ & $0.9 \mathrm{a}$ & $1.2 \mathrm{~b}$ \\
CV-4 & $30.3 \mathrm{a}$ & $24.8 \mathrm{~b}$ & $0.5 \mathrm{~b}$ & $0.8 \mathrm{bc}$ \\
\hline
\end{tabular}

CV1: Local cassava cultivar; CV2: Improved cultivar (92/0326); CV3: Improved cultivar (81/00110); CV4: Improved cultivar (W94/009). Mean values in the same column followed by same letter in a column are not significantly different according to Duncan's Multiple Range Test at $p=0.05$.

Table 3. Evolution of anthracnose on cassava cultivars and correlation with HCN concentration.

\begin{tabular}{llllllll}
\hline $\begin{array}{l}\text { Cassava } \\
\text { cultivars }\end{array}$ & $\begin{array}{l}\text { 120 DAP } \\
\text { Incidence } \\
(\boldsymbol{\%})\end{array}$ & $\begin{array}{l}\text { Severity } \\
(\boldsymbol{\%})\end{array}$ & $\begin{array}{l}\text { Incidence } \\
(\boldsymbol{\%})\end{array}$ & $\begin{array}{l}\text { Severity } \\
(\boldsymbol{\%})\end{array}$ & \multicolumn{2}{l}{ Mean values of disease and cyanogenic acid } \\
$\mathbf{( \% )}$ & Severity $(\boldsymbol{\%})$ & $\begin{array}{l}\text { HCN } \\
\text { concentration }\end{array}$ \\
\hline $\mathrm{CV}-1$ & $35.3 \mathrm{~b}$ & $4.4 \mathrm{c}$ & $40.2 \mathrm{c}$ & $21.4 \mathrm{c}$ & $37.6 \mathrm{a}$ & $12.9 \mathrm{a}$ & $0.5 \mathrm{a}$ \\
$\mathrm{CV}-2$ & $19.1 \mathrm{a}$ & $2.4 \mathrm{a}$ & $20.5 \mathrm{a}$ & $5.5 \mathrm{a}$ & $19.8 \mathrm{~b}$ & $4.0 \mathrm{~b}$ & $1,1 \mathrm{~b}$ \\
$\mathrm{CV}-3$ & $30.8 \mathrm{~b}$ & $3.8 \mathrm{bc}$ & $31.2 \mathrm{~b}$ & $17.8 \mathrm{bc}$ & $31.0 \mathrm{a}$ & $10,2 \mathrm{a}$ & $0.6 \mathrm{a}$ \\
$\mathrm{CV}-4$ & $23.2 \mathrm{a}$ & $2.7 \mathrm{a}$ & $25.7 \mathrm{a}$ & $5.3 \mathrm{a}$ & $24.5 \mathrm{bc}$ & $4.0 \mathrm{~b}$ & $1.2 \mathrm{~b}$ \\
\hline
\end{tabular}

CV1: Local cassava cultivar; CV2: Improved cultivar (92/0326); CV3: Improved cultivar (81/00110); CV4: Improved cultivar (W94/009). Mean values in the same column followed by same letter are not significantly different according to Duncan's Multiple Range Test at $p=0.05$.

\section{Evolution of anthracnose on different cassava cultivars and correlation with $\mathrm{HCN}$ concentration}

Disease incidence and severity varied from one cultivar to another, with significant differences $(p<0.05)$ between more acid and less acid cultivars (Table 3 ).

The incidences recorded at $120 \mathrm{DAP}$, on the plots of CV1, CV3, CV2 and CV4 were 35.3, 30.8, 19.1 and $23.2 \%$ respectively. At $210 \mathrm{DAP}$ the incidence of CAD increased in all plots and high values were obtained on CV1 (40.2\%) and CV3 (31.2\%), while those of CV2 (20.5\%) and CV4 (25.7\%) were low, showing a significant difference $(p<0.05)$ between the two groups of cultivars.

The severity of CAD on CV1 (21.4\%) and CV3 (17.8\%) at 210 DAP (rainy season) was approximately five times higher than those obtained in the dry season at 120 DAP (4.4 and 3.8\% respectively) (Table 3). Cultivars CV2 and CV4 showed higher tolerance to anthracnose with very low disease increase (e.g. severity on CV2 and CV4 was 2.4 and $2.7 \%$ at 120 DAP, 5.5 and $5.3 \%$ at 210 DAP). Average values of disease rates and $\mathrm{HCN}$ in cassava leaves show a correlation between cyanide concentration and disease resistance (Table 3 ).

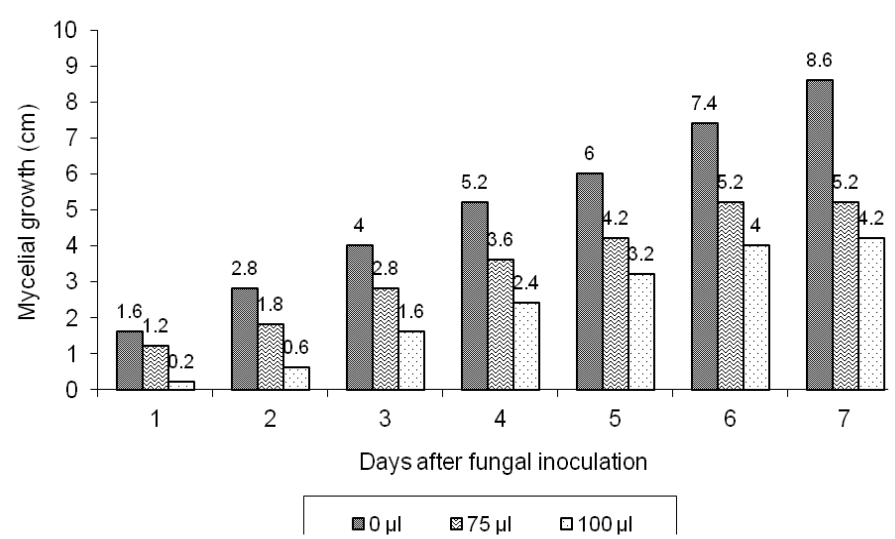

Fig. 2: Effect of different concentrations of HCN extracts on mycelial radial growth of Colletotrichum gloeosporioides.

\section{Inhibitory effect of $\mathrm{HCN}$ extract on in vitro growth of C. gloeosporioides}

To confirm the role of cyanogenic substances in the defence of cassava against anthracnose, the biological test on PDA medium showed that the doses of HCN extract used $(75$ and $100 \mu \mathrm{L})$ significantly $(p<0.05)$ reduced radial growth of $C$. gloeosporioides mycelium two days after fungal inoculation (Fig. 2). The diameter of the fungal growth recorded two days after incubation (DAI) was $2.8 \mathrm{~cm}$ in control plates, $1.8 \mathrm{~cm}$ in treated 
plates with $75 \mu \mathrm{L}$ of $\mathrm{HCN}$ extract and $0.6 \mathrm{~cm}$ in plates treated with $100 \mu \mathrm{L}$ of $\mathrm{HCN}$, showing significant differences $(p<0.05)$ compared to the control (Fig. 2). Similar results were also recorded for all observations done until seven DAI (e.g. the diameter of fungal growth recorded seven DAI was $8.6,5.2$ and $4.2 \mathrm{~cm}$ respectively in control, plates treated with 75 and $100 \mu \mathrm{L}$ of $\mathrm{HCN}$ extract).

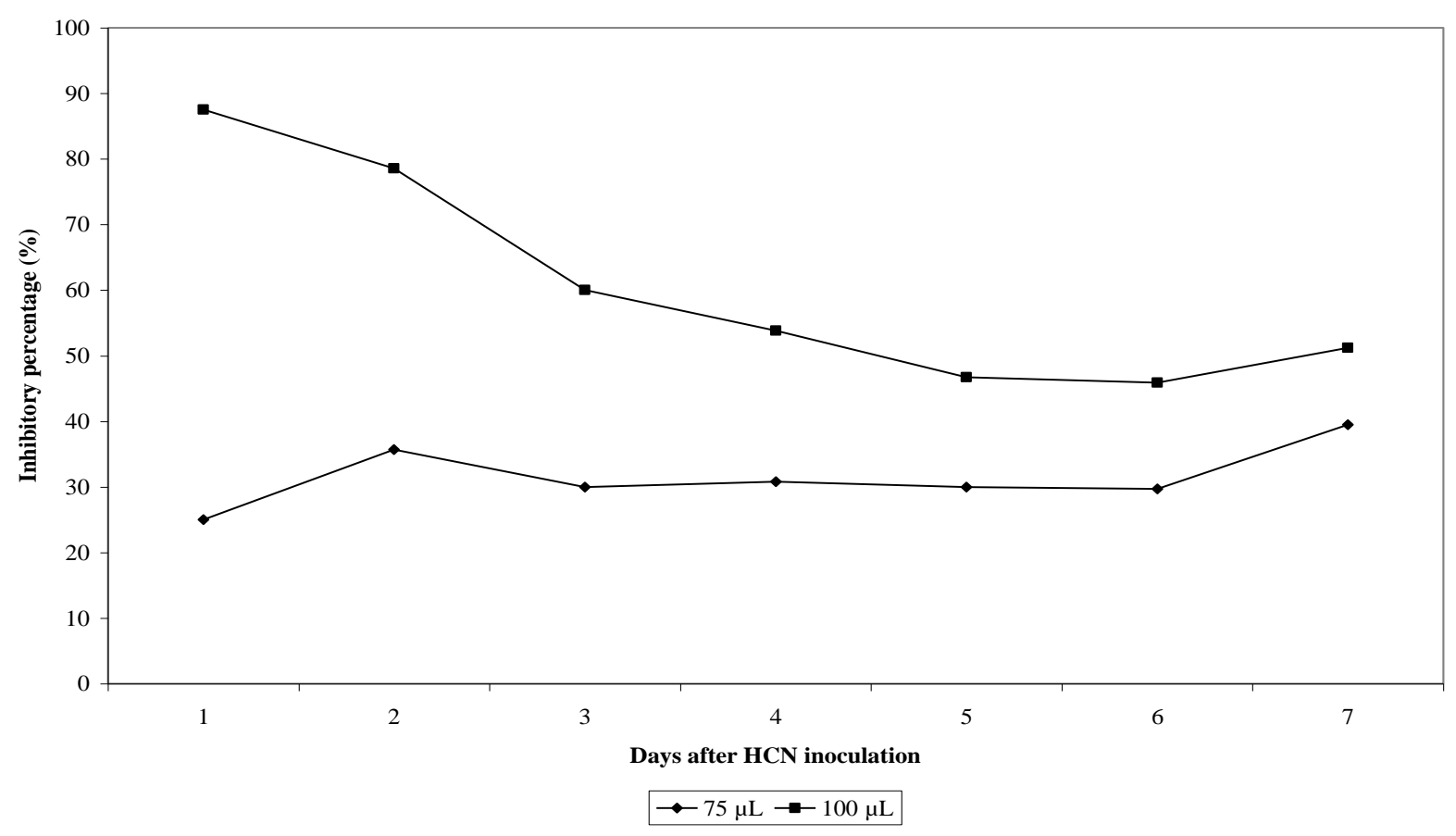

Fig. 3: Variation of Inhibitory percentage of HCN extract on Colletotrichum gloeosporioides in PDA medium.

The effect of HCN extract (e.g. $100 \mu \mathrm{L}$ ) was very high on the first and second DAI, with inhibition percentages of 87.5 and $78.6 \%$ respectively. However, the inhibition percentage progressively decreased to $51.2 \%$ after seven days. For the $75 \mu \mathrm{L}$ dose, the inhibitory effect of $\mathrm{HCN}$ extract increased from the first to seven DAI, but the values were low when compared with the $100 \mu \mathrm{L}$ dose (Fig. 3).

\section{Discussion}

The leaves and tubers of cassava plant containing cyanogenic glycosides liberate HCN in complete hydrolysis (Harborne, 1998). These substances are very dangerous for human and animal health. Studies carried out by Hoofman (1998) showed that the lethal dose of cyanide in cassava varies between $0.5-3.5 \mathrm{mg} / \mathrm{kg}$ of human weight and $2 \mathrm{mg} / \mathrm{kg}$ for animal. The intoxication of $\mathrm{HCN}$ in cassava can be avoided by different ways e.g. fermentation, soaking, chopping, boiling and drying (Kemdirim et al., 1995). But cyanogenic glycosides can also be use in natural defence of plant. The aim of this study was to show the relation between cyanogenic acid concentration in cassava leaves and resistance to anthracnose.
The HCN concentration in cassava cultivars tested in this study varied with cultivar, in function of the age of the plant and the presence of pathogens. Mc Mahon and Sayre (1994) studied the possible role of HCN in the biology and feeding or nutritive behaviour of the cassava burrowing bug (Cyrtomenus bergi F) and reported similar results. Studies of Lieberei (2007) also showed that cyanogenic substances $(\mathrm{HCN})$ concentration depends on the age of the leaves of rubber tree and they can be use as molecular markers in Hevea ssp. breeding for defence against South American leaf blight.

The HCN concentration recorded in all the cultivars regardless of the differences between them at 120 DAP (the beginning of flowering phase, which started in the dry season) was relatively low. At this same period, the degree of cassava stems and leaves infection by cassava anthracnose disease (CAD) was also low. Observations made at 210 DAP (tuber forming phase) in the rainy season indicated that the severity of CAD was high on all the cultivars compared to observations made 120 DAP. The increase in disease severity recorded at 210 DAP might be explained by the establishment of favourable atmospheric conditions for the installation, propagation and development of the disease. This is in line with 
earlier studies done by Nwankiti and Okpala (1984) as well as those of Bala (1994) and Fokunang et al. (1999).

Chemical analyses of leaves realized at 210 DAP showed an increase in HCN concentration on different cultivars. As reported by Bala (1994) and by Lieberei (1988a, 1988b and 2007), cyanogenic substances are best mobilized in the presence of pathogens. Atmospheric conditions and age of the plant also play a role in the mobilization of these cyanogenic substances (Belloti and Arias, 1994; Ambang et al., 2008). High temperature 27$30^{\circ} \mathrm{C}$ (as in the dry season) leads to a degradation of cyanogens (Kemdirim et al., 1995; Siritunga et al., 2004). On the other hand, during the rainy season, there is high activity in the plant especially in the young leaves. This leads to an increase in the concentration of cyanogenic substances which later accumulate in the vacuoles of older leaves. Other studies have demonstrated the relationship between atmospheric conditions and cyanogenic substances (Lieberei, 2007; Kunkeaw et al., 2010) which could explain the HCN increase between 120 DAP (dry season) and 210 DAP (humid season). There was also a positive relationship between $\mathrm{HCN}$ concentration in cassava leaves and tolerance to CAD. Low cyanide cultivars CV1 and CV3 were more susceptible to $C$. gloeosporioides than CV2 and CV4 with high HCN. These results confirm those obtained by Lieberei (1988a, 2007) in similar research on rubber tree and those of Kunkeaw et al. (2010) and also those of De Silva et al. (2009) on cassava.

The high inhibitory effect of HCN extracts observed on in vitro growth of $C$. gloeosporioides (causal agent of CAD) confirms the fact that cyanogenic substances actively take part in the defence of plants that produce them (Bourdoux et al., 1980, Lieberei, 1988b, Owolade et al., 2005; De Silva et al., 2009; Kunkeaw et al., 2010). Similar results were obtained also by Al Sobeai (2016) in his work on in vitro evaluation of aqueous and organic extracts of Anastatica hierochuntica against pathogenic bacteria. The decrease in inhibitory effect of $\mathrm{HCN}$ extract observed in Petri dishes after two to seven days of fungal growth could be due to the volatile nature of cyanogenic substances once the cassava organs are crushed (Kemdirim et al., 1995). This confirms the biodegradable nature of $\mathrm{HCN}$ extract. In this work the distillation method in closed vessel and the $\mathrm{NaOH}$ solution added in a closed flask to trap $\mathrm{HCN}$, permit to conserve $\mathrm{HCN}$ during laboratory experiments. All the solutes used in the extraction process had no effect on fungal growth as it was shown in our previous research (Ambang et al., 2010). Therefore, cyanogenic substances in cassava leaves could be exploited in selection programs for the protection against foliar diseases, as demonstrated by Lieberei (2007) and Siritunga et al. (2004) in similar works on rubber tree and cassava respectively. This study showed that there is a relationship between $\mathrm{HCN}$ concentration in cassava leaves and resistance to $\mathrm{CAD}$. Thus, knowing that there are many and simple methods to avoid cyanogenic intoxication in cassava products, more cyanide and tolerant cultivars can be use for a high yield tuber production in African countries to resolve famine problems.

\section{Conflict of interest statement}

Authors declare that they have no conflict of interest.

\section{Acknowledgement}

Authors are thankful to Dr. Fotso Martin of the IMPM laboratory (MINRESI, Yaounde), for help to obtain HCN extract. Thanks equally go to G. Ntsomboh and G. Chewachong for translation.

\section{References}

Al Sobeai, S.M., 2016. In vitro cytotoxicity and antibacterial evaluation of aqueous, methanolic and ethanolic extracts of Anastatica hierochuntica against pathogenic bacteria. Int. J. Curr. Res. Biosci. Plant. Biol. 3(6), 14-22.

Aiyelari, E.A., Ndaeyo, N.U., Agboola, A.A., 2002. Effects of tillage practices on growth and yield of cassava (Manihot esculenta Crantz) and some soil properties in Ibadan, South western Nigeria. Tropicultura. 20, 29-36.

Akinbo, O., Gedil, M., Ekpo, E.J.A., Oladele, J., Dixon, A.G.O., 2007. Detection of RAPD markers-linked resistance to cassava anthracnose disease. Afr. J. Biotechnol. 6, 677-682.

Ambang, Z., Amougou, A., Ndongo, B., Nantia, J., Nyobe, L., Ongono, Y.S.B., 2007. Tolérance de quelques cultivars de manioc ( $M$. esculenta) et de l'espèce sauvage ( $M$. glaziovii) à la mosaïque virale africaine et à la cercosporiose. Tropicultura. 25, 140-145.

Ambang, Z., Kameni, D.W., Ndongo, B., Maho, Y.J.E., Ngoh, D.J.P., Asanga, N.A., 2008. Mobilisation de l'acide cyanhydrique $(\mathrm{HCN})$ dans les feuilles de manioc (Manihot esculenta Crantz) en fonction des phases de développement des plantes, du degré d'infection et des variations climatiques. In: Proceedings of the 15th Annual Conference of Cameroon Biosciences Society (CBS), Yaounde. pp.11-22.

Ambang, Z., Amougou, A., Ndongo, B., Nantia, J., Chewachong, G.M., 2009. Résistance à la mosaïque virale de Manihot glaziovii par greffage sur M. esculenta. Tropicultura. 27, 8-14. 
Ambang, Z., Ngoh, D.J.P., Essono, G., B., Chewachong, G., Asseng, C.C., 2010. Effect of Thevetia peruviana seeds extract on in vitro growth of four strains of Phytophthora megakarya. Plant Omics J. 3, 70-76.

Babu, A.M., Philip, T., Kariappa, B.K., Kamble, C.K., 2008. Scanning electron microscopy of the infection process of Cercospora henningsii on cassava leaves. J. Phytopathol. 157, 57-62.

Bakak, M.P., 1992. Yam anthracnose assessment of the virulence of isolates of Colletotrichum gloeosporioides on Dioscorea spp. MSc. Dissertation, University of Reading.

Bala, N., 1994. Cyanogenesis in cassava. In: First International Scientific Meeting of the Cassava Biotechnology Network. CIAT, Cali. pp.424- 427.

Belloti, A.C., Riis, L., 1994. Cassava cyanogenic potential and resistance to pest and diseases. Acta Hortic. 375, 141-152.

Belloti, A.C., Arias, B.V., 1994. The possible role of HCN in the biology and feeding behaviour of the cassava burrowing bug (Cyrtomenus bergi F.). In: First International Scientific Meeting of Cassava Biotechnology Network. CIAT, Cali. pp.406-410.

Bilgrami, K.S., Dube, H.C., 1984. A textbook of Modern Plant Pathology. Shahdara, India. 344p.

Bourdoux, P., Mafuta, M., Hanson, A., Ermans, A.M., 1980. Cassava toxicity. Role of Linamarin. In: Role of Cassava in Etiology of Endemic Goitre and Cretinism (Eds.: Ermans, A.M., Mbulamoko, N.M., Delange, F., Ahluwalia, R.). Int. Develop. Res. Center, Ottawa. pp.1527.

Bruitn, G.H., 1973. The cyanogenic character of cassava $(M$. esculenta). In: Chronic Cassava Toxicity. Int. Develop. Res. Center, London, 43-48.

Conn, E., 1973. Cyanogenic glycosides, their occurrence, biosynthesis and function. In: Chronic Cassava Toxicity. Int. Develop. Res. Center, London, 55-63.

Coursey, D.G., Brooth, R.H., 1977. Root and tuber crops. In: Food Crops of the Lowland Tropics (Eds.: Leakey, C.L.A., Wills, J.B.). Oxford University Press, England. pp.75-96.

De Silva, A.C.D., Nelza, de Luma, P.S., Alisson, de Virucius, A., Cecilio, Frois, C.J., 2009. In vitro effect of plant compounds on the fungus Colletotrichum gloeosporioides Penz. isolated from passion fruit. Ciênc. Agrotec. 33, 1853-1860.

Fauquet, C.M., Fargette, D., 1990. African cassava mosaic virus: Etiology, epidemiology and control. Plant Dis. 74, 404- 411.

Fews, 1998. La mosaïque du manioc menace la sécurité alimentaire en Afrique de l'Est. Rapport spécial 98, 11-15.

Fokunang, C.N., Akem, C.N., Ikotun, T., Dixon, A.G.O., 1999. Effect of planting season on anthracnose disease development. Crop Prot. 18, 407-413.

Fokunang, C.N., Akem, C.N., Ikotun, T., Dixon, A.G.O., Tembe, E.A. 2000. Role of the insect vector, Pseudotheraptus devastans in cassava anthracnose disease development. Eur. J. Plant Pathol. 106, 319-327.
Fokunang, C.N., Dixon, A.G.O., Ikotun, T., Akem, C.N., Tembe, E.A., 2002. Rapid screening method of cassava cultivars for resistance to Colletotrichum gloeosporioides f.sp. manihotis. J. Phytopathol. 150, 6-12.

Grace, M.R., 1978. Traitement du manioc. In : Production Végétale et Protection des Plantes. Collection FAO, Rome, 3, 114-115.

Githunguri, C.M., Mwiti, S., Migwa, Y., 2007. Cyanogenic potentials of early bulking cassava planted at Katumani, a semi-arid area of Eastern Kenya. Afr. Crop Sci. Proc. 8, 909-912.

Harborne, J.B., 1998. Cyanide glycosides and quantitative analysis of HCN. In: Phytochemical Methods: A Guide to Modern Techniques of Plant Analysis. Springer. pp 215217.

Hoofman, L. 1998. Konzo and Dietary Cyanogens from Cassava in Cameroon: Nutrition in Low Countries. Individual study $\mathrm{n}^{\circ} 6$, Department of Medical Science Nutrition, Uppsala University. 35p.

Ikotun, T., Osiru, D.S.O., 1990. Le manioc en Afrique tropicale. IITA, Ibadan. 190p.

Kemdirim, O., Chukwu, O., Achinewhu, S., 1995. Effect of traditional processing of cassava on the cyanide content of gari and cassava flour. Plant Food Human Nutr. 48, $335-$ 339.

Kunkeaw, S., Woropong, J., Smith, D.R., Triwitayakorio, K., 2010. An in vitro detached leaf assay for pre-screening resistance to anthracnose disease in cassava (Manihot esculenta Crantz). Austral. Plant Pathol. 39, 547-550.

Lepoivre, P., 2003. Phytopathologie. Presses Agronomiques de Gembloux, 427p.

Lieberei, R., 1988a. Relationship of cyanogenic capacity (HCN-c) of rubber tree Hevea brasiliensis to susceptibility to Microcyclus ulei, the agent causing South American leaf blight. J. Phytopathol. 122, 54-67.

Lieberei, R., 1988b. The role of cyanide and cyanogenesis in plant interactions. In: No. 140 CIBA-Foundation Symposium Cyanide Compounds in Biology (Eds.: Evered, D., Gamety, S. F.). Wiley, Chichester, UK. pp. 195-200.

Lieberei, R., 2007. South American leaf blight of rubber tree (Hevea spp.): New steps in plant domestication using physiological features and molecular markers. Ann. Bot. 100, 1125-1142.

Louembé, D., Kobawila, S.C., Keléké. S., Diakabana, P., NKoussou, M.B., 2002. Rouissage des tubercules de manioc à partir de "pied de cuve" à base de manioc roui. Tropicultura. 20, 118-124.

Lozano, J.C., Belloti, A.C., Reys, J.A., Howland, R.H., Leihner, D., Doll, J., 1981. Field problems in cassava. CIAT (Centro International de Agricultura Tropical), Cali, Colombia. pp.5-25.

Makambila, C., 1987. Etude de l'anthracnose du manioc (Manihot esculenta Crantz) et son agent pathogène Colletotrichum gloeosporioides (Penz) f.sp. manihotis (Henn). Thèse de Doctorat ès Sciences naturelles, Université de Clermont-Ferrand II (France). 493p. 
Marley, P.S., Ajayi, O., 2003. Effect of sowing date on anthracnose of sorghum in the Nigerian Sudan savana. Tropicultura. 21, 117-121.

Mc Mahon, J.M., Sayre, R.T., 1994. Differential biosynthesis and transport of Linamarin in high and low cyanide cultivars of cassava (Manihot esculenta). In: First International Scientific Meeting of the Cassava Biotechnology Network, CIAT, Cali. pp.376-379.

Muyolo, G., 1984. Studies on the interaction between Xanthomonas campestris p.v. manihotis Berthet and Bonder and Colletotrichum gloeosporioides f.sp. manihotis on cassava and its effects on yield. M.Phil. Thesis, University of Ibadan, Nigeria. 130p.

Nielsen, K.A., Olsen, C.E., Pontopidan, K., Moller, B.L., 2002. Leucine-dirived cyano glycosides in Barley. Plant Physiol. 129, 1066-1075.

Nkalubo, S., Melis, R., Laing, M.D., Opio, F., 2007. Yield loss associated with anthracnose disease on Ugandan marketclass dry bean cultivars. Afr. Crop Sci. Conf. Proc. 8, 909912.

Nwankiti, A.O., Okpala, E.U., 1984. Anthracnose/blotch disease caused by Colletotrichum gloeosporioides Penzig: Effect of infected leaf removal on disease severity, incidence and yield of three local cultivars of Dioscorea alata L. Beitr. Trop. Landwirtsch. Veterinarmed. 22(2), 179-185.

Obame Minko, O., Békon, A.K., 2005. Etude de l'entomofaune associée à la cochenille du manioc Phencoccus manihoti Matile-Ferrero, en Côte d'Ivoire. Tropicultura. 23, 136-140.

Obilo, O.P., Ikotun, B., Ihejinka, G.O., Ibeawuchi, I.I., Oben, T.T., 2010. The effect of the incidence of cassava anthracnose disease (CAD) on the performance and yield of cassava cultivars. Crop Protect. 29, 482-486.

Olubamila, Balogun-Kuku, O.I., Longe, O.G., Iyayi, E.A., Agunbiade, J.A., 2001. Cassava leaf/cocoa Husk inclusions in layer smash produced quality cheap feeds. Tropicultura.19, 123-126.

Osbourn, A.E., 1996. Preformed antimicrobial compounds and plant defence against fungal attack. Plant Cell. 8, 18211831.

Ouzounov, I.S., 1988. Cassava diseases. In: Tropical Phytopathology. RUDN Edn., Moscow. pp.114-134.

Owolade, O.F., Dixon, A.G.O., Adeoti, A.A., Osunloja, S.O., 2005. Sources of resistance to cassava anthracnose disease. Afr. J. Biotechnol. 4, 570-572.

Owolade, O.F., Dixon, A.G.O., Adeoti, A.Y.A., 2006. Diallel analysis of cassava genotypes to anthracnose disease. World J. Agric. Sci. 2, 98-104.

Ritchie, B., 1991. Practical Techniques in Plant Pathology. CAB International, Wallingford.

Sanni, L., Maziya-Dixon, B., Patino, M., Akoroda, M., Ezedima, C., Okechukwu, R., Lemchi, J., 2005. Value addition to cassava in Africa: Challenges and opportunities. Afr. Crop Sci. Conf. Proc. 7, 583-590.

Scott, G., Best, R., Rosegrant, M., Bokanga, M., 2000. Roots and tubers in the global food system. A vision statement to the year 2020. Food, Agriculture and the Environment Discussion paper. IFPRI-CIP Washington DC. 25p.

Singh, G., Padhvay, R.K., Narayaman, G.S., Padmkumari, K.P., Rao, G.P. 1993. Chemical and fungitoxic investigation on the essential oil of Citrus. Pers. Deutsche Zeits half Pflangenfrankenenen flanzenschutz. 100, 69-74.

Siritunga, D., Arias-Garzon, D., White, W., Sayre, R.T., 2004. Over-expression of hydroxynitrile lyase in transgenic cassava roots accelerates cyanogenesis and food detoxication. Plant Biotechnol. J. 2, 37-43.

Tchumakov, A.E., Zaharova, T.I. 1990. Elucidation and statistical analysis of disease development. In: Plant Disease Damages. Agroprom-Izdat, Moscow. pp.5-60.

Were, H.K., Winter, S., Maiss, E., 2007. Characterisation and distribution of cassava viruses in Kenya. Afr. Crop Sci. Conf. Proc. 8, 909-912.

Wood, R.K.S., Jellis, G., 1984. Plant Diseases: Infection, Damage and Loss. ISBN Britain. 327p.

Wright, R.M., 1996. Jamaica’s Energy: Old Prospects, New Resources. Twin Guinep Publishers/Stephenson's Litho Press. 159p.

\section{How to cite this article:}

Ambang, Z., Maho, Y. J. E., Essono G. G., Ndongo, B., Heu, A., 2016. Cyanogenic acid (HCN) concentration in leaves of four cassava varieties and resistance to anthracnose disease in Cameroon. Int. J. Curr. Res. Biosci. Plant Biol. 3(7), 56-64. doi: http://dx.doi.org/10.20546/ijcrbp.2016.307.009 